\title{
Transformation of the cost management system for implementing business projects in digital entrepreneurship
}

\author{
Sergey Vasin ${ }^{1}$, Leyla Gamidullaeva ${ }^{1, *}$, and Vardan Mkrtchian ${ }^{1}$ \\ ${ }^{1}$ Penza State University, 440026, 40 Krasnaya str., Penza, Russia
}

\begin{abstract}
The report of the International Bank for Reconstruction and Development indicates that "digital technology has repeatedly expanded the information base, reduced information costs and created information products. This has facilitated seeking for information, its comparing and exchanging. Moreover, this has contributed to enhancing cohesion and cooperation between economic entities, which in its turn has affected the ways of companies' operational activity, finding opportunities for people and interacting between citizens and their governments". The paper deals with the issues specified in the hypothesis that the changes in strategic, tactical and operational cost management are required due to the development of digital entrepreneurship, as well as the changes in goals, criteria for assessing the achievement of goals, subject and object of management and methods of cost management.
\end{abstract}

\section{Introduction}

Cost management is not the key activity in the management of business projects in digital entrepreneurship, but it is required for achieving a certain economic result, increasing the efficiency of the enterprise.

In order to develop a unified theory and methods for managing the costs of digital technology users, it is necessary to summarise the results of theoretical studies in various spheres of scientific activity, i.e. organisation, management, economy and cost management in particular, as well as to study practical experience in managing costs in the field of digital entrepreneurship.

We consider it expedient to begin studying the common practice of cost management with analysing the existing formalized concepts of cost management, i.e. from standards. The cost management standards defining the content of cost management in practice include:

- International standards for cost management (IFRS);

- National standards of cost management (FL (federal laws) and RAS (Russian accounting standards));

- Quality standards (ISO);

\footnotetext{
* Corresponding author: gamidullaeva@gmail.com
} 
- Branch instructions on cost accounting and output cost determination;

- Tax Code of the Russian Federation (TC of the RF);

- Laws and bylaws defining the specific features of cost management depending on the organisational and legal form and size of the enterprise;

- Orders on accounting policy of research targets;

- Other standards (including those in the sphere of ecology and life safety, protection of trade secrets, labour resources management).

\section{Results}

At present, when establishing a cost management system, the enterprises in the Russian Federation are guided by a four-level regulatory accounting system that is moving towards the IFRS. It should be noted that since December 2011, the International Financial Reporting Standards were enacted on the territory of the Russian Federation. The main standard in financial accounting of costs, which production enterprises must obey, is the enactment on accounting "Expenses of the organisation" RAS 10/99. It is also necessary to study some paragraphs of the enactments on accounting "Segment information" (RAS 12/2010), "Accounting of costs for natural resources development" (RAS 24/2011), "Accounting of costs for research, development and production operation" RAS 17/02».

The enactment "Expenses of the organisation" specifies the rules for arranging information on the costs of commercial organisations (other than credit and insurance organisations) in accounting that are legal entities under the laws of the Russian Federation.

In the text of the enactment, the concept of expenses is defined as "the reduction of economic benefits resulting from the outflow of assets (cash, other property) and (or) the emergence of liabilities, leading to reducing capital of this organisation, except for reducing contributions as defined by the participants (owners of property)". That means this includes reducing stocks of finished goods in a warehouse in the course of their providing to buyers. In this case, the costs of goods manufactured are transformed into the costs for manufactured goods sold in the reporting period, and the costs participate in forming the financial result. The possible temporary divergence between the costs of goods manufactured for a certain period and the costs of the period should be noted. Interpreting the concept of expenses in the enactment "Expenses of the organisation" as cash outflow and capital reduction (in the part of accounts payable) is undoubtedly associated with cost management, but requires separate consideration from the viewpoint of financial management, since "the outflow of assets is referred to as payment".

The expenses of the organisation, depending on their nature, conditions for implementing and activities of the organisation are divided into normal business expenses and miscellaneous expenses.

The rules for accounting costs for producing goods, selling goods, executing work and providing services in the context of elements and items, and the rules for calculating cost for products (work, services) are set by specific standard regulations and methodological guidelines for accounting (Table 2).

At present, the Russian theory and practice of cost accounting offers a range of methods for calculating the cost for production, including absorption costing, variable costing, normative, ordering, and processing methods. They are recorded in the accounting policies of enterprises. However, Russian accounting standards do not include methodological guidelines on this matter.

Table 2. Regulation of cost management in the RF in methodological guidelines on specific types of economic activity. 


\begin{tabular}{|c|c|}
\hline Standard regulation & $\begin{array}{c}\text { Issues covered by the standard regulation and related to establishing } \\
\text { and managing accounting }\end{array}$ \\
\hline $\begin{array}{l}\text { Methodological guidelines } \\
\text { on the issues of planning } \\
\text { and accounting costs for } \\
\text { manufacturing and selling } \\
\text { products (works, services) } \\
\text { at publishing enterprises }\end{array}$ & $\begin{array}{l}\text { The following opportunities are provided for the publishing house: } \\
\text { - establishing the organisational form of accounting based on the } \\
\text { type of organisation and specific conditions of management; } \\
\text { - defining the form and methods of accounting, as well as } \\
\text { technology for processing accounting information in accordance } \\
\text { with the established procedure; } \\
\text { - developing the system of management accounting, reporting and } \\
\text { control; } \\
\text { The methods for planning (budgeting) costs for issuing and selling } \\
\text { printed output and the model system of budgets and their forms are } \\
\text { recommended. }\end{array}$ \\
\hline $\begin{array}{l}\text { Methodological guidelines } \\
\text { for planning, accounting } \\
\text { and calculating production } \\
\text { costs at bakery enterprises }\end{array}$ & $\begin{array}{l}\text { The approaches to organising cost accounting are defined. } \\
\text { Accounting should include: a) a system of accounting costs for } \\
\text { production in the context of their individual items; b) a system of } \\
\text { accounting the output of finished products in physical terms; c) a } \\
\text { system of accounting costs for the sale of finished products in the } \\
\text { context of their individual items; d) a system of accounting the sale } \\
\text { of finished goods in value and physical terms; e) a document } \\
\text { management system ensuring timely and correct treatment of } \\
\text { relevant indicators. } \\
\text { The goal of planning costs for manufacturing and selling products is } \\
\text { defined, as well as its main stages, types of budgets used } \\
\text { (operational and financial). }\end{array}$ \\
\hline $\begin{array}{l}\text { Methodological guidelines } \\
\text { for planning, accounting } \\
\text { costs for manufacturing } \\
\text { and selling products } \\
\text { (works, services) and } \\
\text { calculating the cost of } \\
\text { production (works and } \\
\text { services) at chemical } \\
\text { enterprises }\end{array}$ & $\begin{array}{l}\text { The methods for using the "direct costing" system in planning, } \\
\text { accounting costs for manufacturing and selling products (works, } \\
\text { services) and calculating the cost of production (works, services) at } \\
\text { the enterprises of chemical industry are specified. }\end{array}$ \\
\hline $\begin{array}{l}\text { Methodological guidelines } \\
\text { on the issues of planning } \\
\text { and accounting costs for } \\
\text { manufacturing and selling } \\
\text { products (works, services) } \\
\text { at printing enterprises }\end{array}$ & $\begin{array}{l}\text { The concept of "budgeting", the stages of financial planning, and the } \\
\text { configuration of the functional budgets system are defined. The } \\
\text { recommended forms of the consolidated budget, functional budgets, } \\
\text { and cost-item budgets, the types of responsibility centres } \\
\text { recommended for identifying are distinguished, as well as the } \\
\text { consolidated budget components: initial forecast data, production } \\
\text { programme, profit and loss balance, enterprise balance, cash flow } \\
\text { statement. }\end{array}$ \\
\hline $\begin{array}{l}\text { Typical guidance on } \\
\text { applying the normative } \\
\text { method of accounting } \\
\text { costs for production and } \\
\text { calculating the standard } \\
\text { (target prime) and actual } \\
\text { cost of production (works) }\end{array}$ & $\begin{array}{l}\text { The concept of the normative method for cost accounting is defined. } \\
\text { The process of the normative method for accounting is described. } \\
\text { The main provisions for developing norms of cost and normative } \\
\text { calculations are elaborated, as well as provisions for accounting } \\
\text { norm changes and divergences of actual costs. The means for } \\
\text { recording and assessing work in progress are proposed, as well as } \\
\text { the means for summary accounting of production costs and } \\
\text { calculating of the actual cost of production (work). Organisational } \\
\text { measures related to introducing the normative accounting method } \\
\text { were developed. }\end{array}$ \\
\hline
\end{tabular}

Sources: $[1,2,3,4,5,6,7,8]$.

The generally accepted rules of cost management, mainly related to fulfilling the accounting function, are presented in the IFRS 2 "Inventories". 
We also consider it necessary to specify here the relations between cost management and current assets management.

The provisions of the standard regulate the rules for selecting calculating methods that affect the amount of profit in the reporting period.

The IFRS 2 "Inventories" also provides guidance on allocating indirect overhead costs of an industrial nature, on distributing integrated production services and on dividing costs between capitalised and non-capitalised ones in the balance sheet. The main provisions of the IFRS 2 "Inventories" will be considered in comparison with the Russian accounting standards given in Table 3.

The fundamental difference between the foreign method of "direct costing" and the accounting incomplete cost (in fact the production cost without general business expenses) should be noted.

Table 3. Comparative analysis of the IFRS 2 "Inventories" and the Russian Accounting Standards.

\begin{tabular}{|c|c|}
\hline IFRS 2 "Inventories" & Russian Accounting Standards (RAS) \\
\hline $\begin{array}{l}\text { The use of absorption costing that } \\
\text { is traditional for Russian } \\
\text { accounting is regulated. "Direct } \\
\text { costing" for financial reporting is } \\
\text { prohibited. }\end{array}$ & $\begin{array}{l}\text { The use of absorption costing and variable costing } \\
\text { presenting gross profit in financial reporting is regulated. } \\
\text { The regulation on applying the chart of accounts for } \\
\text { accounting in the explanations to the account } 26 \text { "General } \\
\text { business expenses" established that "these expenses as } \\
\text { conditional-permanent can be debited to the account } 90 \\
\text { "Sales". }\end{array}$ \\
\hline $\begin{array}{l}\text { Regulates the procedure for } \\
\text { classifying excessive costs as } \\
\text { periodic, i.e. in full amount } \\
\text { attributed to decreasing profit in } \\
\text { the reporting period. Excessive } \\
\text { losses of raw materials, wages, etc. } \\
\text { should not be considered in the } \\
\text { reserves defined in the asset } \\
\text { balance. The normative method is } \\
\text { allowed for estimating stocks of } \\
\text { materials, work in progress and } \\
\text { finished products. }\end{array}$ & $\begin{array}{l}\text { The use of the normative method is allowed (with } \\
\text { identifying the special account "Release of products, works, } \\
\text { and services" in the chart of accounts). In practice, however, } \\
\text { the divergences are distributed between balances of work in } \\
\text { progress, finished goods and sold products due to the } \\
\text { influence of tax accounting. }\end{array}$ \\
\hline $\begin{array}{l}\text { The concept of indirect costs is } \\
\text { given. They are the costs that } \\
\text { cannot be directly or economically } \\
\text { attributed to the cost of a particular } \\
\text { product (service). } \\
\text { Three groups of costs included in } \\
\text { the cost of production, were } \\
\text { defined: (1) production variable } \\
\text { direct costs, (2) production variable } \\
\text { indirect costs, (3) production fixed } \\
\text { indirect costs (production } \\
\text { overheads). }\end{array}$ & $\begin{array}{l}\text { It is not specified in the RAS. It is given in the chapter } 25 \text { of } \\
\text { the Tax Code of the Russian Federation. While arranging } \\
\text { normal business expenses, they should be grouped } \\
\text { according to the following components: material costs, } \\
\text { labour costs, social security contributions, depreciation, and } \\
\text { miscellaneous costs. }\end{array}$ \\
\hline $\begin{array}{l}\text { Variable indirect production costs } \\
\text { are included in the cost of } \\
\text { production in proportion to the } \\
\text { actual volume of output. That is, } \\
\text { the basis for distributing these costs } \\
\text { is the indicator "actual production } \\
\text { capacity" (general production } \\
\text { costs). }\end{array}$ & $\begin{array}{l}\text { There are no norms regulating the inclusion indirect } \\
\text { variables and fixed production costs in the input cost of } \\
\text { products formed in the accounting (financial accounting) in } \\
\text { the Russian legislation (it is advisory to use industry } \\
\text { guidelines and recommendations). }\end{array}$ \\
\hline Constant overhead production costs & \\
\hline
\end{tabular}


(general business expenses) are included in the production cost in proportion to the forecast value of the normal production capacity. Normal output is the output that is expected to be derived according to the average for several periods or seasons of operation under normal conditions, taking into account the productivity losses due to scheduled maintenance. The actual volume of production can be used if it approximates the normal performance.

Sales costs (commercial expenses) are recognized as expenses in the period of origin.

According to the paragraph 9 of RAS 10/99, the organisations have the right to recognise commercial expenses in full in the reporting year as normal business expenses. At the same time, the costs for packaging and transporting are subject to distribution within partial recovery of costs associated with selling products and services.

The qualification requirements for personnel involved in cost management, for example, the head of the planning and economic department include the requirements for obtaining the following cost management methods:

- "Determining the cost price of commercial products,

- Developing standards for material and labour costs, wholesale and retail prices;

- Defining the economic efficiency in installing new equipment, introducing new technology, measures to improve the competitiveness of products, improving labour organisation and management;

- Russian and foreign experience in efficient organisation of economic activity at the enterprise in market economy".

It also specifies that the economist "performs calculations for material, labour and financial costs required for manufacturing and selling products, developing new products, acquiring advanced techniques and equipment. The economist conducts economic analysis of business activities by the enterprise and its divisions, identifies production reserves, develops measures to ensure economy, improves production profitability, products competitiveness, labour productivity, reduces production and sales costs, eliminates losses and unproductive expenses, and identifies the opportunities for additional output". The economist must know the "procedure for developing standards for material, labour and financial costs". That is, proficiency in legislative enactments does not provide the cost management agent with the required knowledge, and the qualification requirements are limited only by the knowledge of the procedure for determining the cost and developing cost standards. In accordance with existing standards, proficiency in cost management methods and information and communication technology is not required.

The standard of the Russian Federation GOST R ISO 9004-2010 "Managing for the sustained success of an organisation. A quality-management approach" declares that "for ensuring efficient and effective use of resources, processes for providing, placing, monitoring, evaluating, optimising, maintaining and protecting such resources should be brought into force" [8].

The recommendations in the section "Resource Management" are submitted to financial resources, human resources (requirements for personnel competence, involvement and motivation are given), partners and suppliers, infrastructure, production environment 
(ergonomics), knowledge, information and technology, natural resources (their use should also conform to the ISO 14000 standards for environmental management).

There have been suggestions that the correct use of standardisation capabilities at the enterprise makes it possible to improve the efficiency of its operation. At the same time, one of the main components of the economic effect at a particular enterprise is the reduction in the cost of standard production. However, according to practitioners, the implementation of the ISO standards at enterprises is often of a formal nature and is mainly ensured by preparing the required documents. In part, this may be due to the general nature of the recommendations, especially in relation to the subject of our research. Thus, the ISO Quality Improvement Programme, if it is developed properly, will lead to decreasing rather than increasing costs.

The best practices in the efficient organisation of cost management abroad will be studied using large successful manufacturing enterprises from Japan, Germany, and the USA as the example, at Matsushita, Siemens, IBM, respectively.

While studying the practice of cost management, we focus on the functions which are not regulated by Russian standards and the implementation of which depends on the skills of enterprise specialists and the priorities of enterprise managers, i.e. organising, forecasting, planning, controlling, and regulating.

The planning system in the Japanese company "Matsushita" is simple, but comprehensive. Every 6 months all branch managers should provide three plans:

- Long-term five-year plan, which is updated as new technology and economic conditions change the prospects of the branch,

- Medium-term two-year plan, which is activated following the implementation of the long-term strategy on increasing production capacities and production of new products. Neither plan is studied by the top managers of the company, although the product group managers pay close attention to them,

- The third plan is a production programme for the forthcoming six-month working period. It is sent by the department managers to senior managers. The plan outlines the monthly long-term estimates of output, sales, profits, inventories, receivables, staff requirements, planned targets for quality management and investment. When there are divergences from the plan, a special group, formed of the department managers and independent controllers, promptly investigates the reasons for the divergences.

The forms of cost management, used in practice, are difficult to classify due to their diversity and information availability concerning nuances (including motives and causeeffect relationships) in management decision-making. The study of publications on practice of contractual works at enterprises in the Voronezh Region allows us to distinguish at least two forms:

- Automated;

- Intuitive.

As far as cost management methods from the perspective of a functional approach is concerned, large production enterprises while managing costs mostly use the Soviet time practices, while at the newly established enterprises there are attempts to introduce modern management methods. Generally, cost management is not formalised at small enterprises.

The choice of the method for accounting costs and calculating the cost of production (works, services) for a particular economic entity depends on many factors. The effective use of the method chosen is based on the degree to which the goals set at the stage of production planning were achieved.

Using the functional approach, we began studying the common practice with the function of cost planning.

The production enterprises are interested in implementing budgeting technology. There are the following types of budgets: current (operational, operating) budgets and financial 
budgets (revenues and expenditures budget (RED), cash flow budget (CFB), and balance sheet budget (BSB)). Cost management using budgeting begins with setting the sales budget. The summary of literary sources and budgeting practice suggests several basic approaches and techniques that allow planning a producing and marketing programme providing the maximum profit and the necessary financial condition:

- Decision-making based on relevant information;

- Defining indicators for management (marginal) analysis, such as multistage marginal revenue, break-even point, financial safety margin, operational (economic) leverage;

- Analysing sales seasonal fluctuation;

- Calculating the limit of acceptable growth in the unchanged and changing financial state.

Relevant information is information essential for management decision-making, usually these are quantitative indicators and qualitative characteristics that differ in alternative options.

The sales break-even point is often calculated on the basis of the historical data given in the annual accounting statements for defining the minimum amount of revenue covering the aggregate costs.

We consider it expedient to use the formula for calculating the break-even point, taking into account the structure of production and sales of goods (formula 1).

$$
\text { Breakeven point }=\frac{\text { Fixed } \cos t s}{\sum_{i=1}^{n} \text { Specificmarg inal revenue } \cdot \text {. Share of product } i \text { in revenue }}
$$

where

$\mathrm{i}$ - a type of products manufactured;

$\mathrm{n}-\mathrm{a}$ number of items produced and marketed.

Specific marginal revenue is calculated in roubles per rouble of revenues from sales. The share of products in revenue is substituted into formula 1 in shares of a unit.

Changing the costs structure and the producing and marketing programme, the company achieves a positive financial result in the key activity.

When calculating the indicators of management analysis, it is necessary to take into account the boundaries in the relevance of obtained values, that is, to monitor implementing the assumptions in the analysis. There are various forms of assumptions adopted while analysing the production break-even, we consider it appropriate to use the achievements of Colin Drury, who defines: "All other variables remain constant; a single product or a permanent range of products sold; profit is calculated according to variable costs; aggregate costs and aggregate income are the linear functions of production volume; only acceptable range of production volumes is analysed; costs can be perfectly divided into permanent and variable components". It should be noted that in this case Colin Drury or the translator use the term "expenses" as a synonym for the concept "costs" in Russian.

Sales seasonal fluctuation effects decision-making in the production policy: either the priority for the balanced load of production capacities, or the focus on reducing stocks of finished products. In the second option, the enterprise will face fluctuations in the utilisation of production capacities and, consequently, with the fact that the cost of production in the low load period is significantly higher than the cost in the high load period. The fluctuations will depend on the changing share of indirect costs per unit of output. There is also an issue in the divergence of the actual capacity utilisation from the budgeted one.

Aleksandr Lednev describes the model for calculating budgetary requirements of costs depending on the level of capacity utilisation and seasonal fluctuations. 


$$
Y_{i}=\left(K_{i} \cdot X\right)+B_{i}
$$

where $\mathrm{Y}_{\mathrm{i}}$ - value of budget item;

$\mathrm{K}_{\mathrm{i}}$ - a slope ratio;

$\mathrm{X}-\mathrm{a}$ level of capacity utilisation;

$\mathrm{B}_{\mathrm{i}}-\mathrm{a}$ minimum value of costs under the conditions of total enterprise shutdown.

Calculating the slope ratio "requires data of two successive months with approximately the same ratio in costs seasonal fluctuations, but with different levels of capacity utilisation. Months are selected in a six-month interval. The slope ratio is determined by formula 3.

$$
K_{i}=\left(\left(Y_{\text {month } 2}-Y_{\text {month } 1}\right) \div\left(X_{\text {month } 2}-X_{\text {month } 1}\right)\right) \div K S,
$$

where $\mathrm{KS}$-, which is introduced on certain cost items and which allows adjusting the planned value depending on the time of year.

According to Aleksandr Lednev, values of seasonal fluctuations ratio are calculated for each cost item according to the statistical analysis and expert estimates of relevant services and can vary from 0.5 to 1.6 . To calculate the planned values of budget items, taking into account the seasonal fluctuations ratio, formula 4 is used.

$$
Y_{i}=\left(\left(K_{i} \cdot X\right)+B_{i}\right) \cdot K S_{i} \text { or } Y_{i}(k s)=Y_{i} \cdot K S_{i}
$$

Having converted formula 4, one can get formula 5, which clearly shows the impact of changing capacity utilisation and seasonal fluctuations.

$$
Y_{i}=\frac{\left(Y_{\text {month } 2}-Y_{\text {month } 1}\right)}{\left(X_{\text {month 2 }}-X_{\text {month 1 }}\right)} \cdot X+B_{i} \cdot K S
$$

For describing the sales frequency rate in view of seasonal fluctuations and price dynamics, Yury Permyakov suggests using the following harmonic function (formula 6) [6].

$$
f(k)=A_{0}+A \cdot \sin \left(\frac{2 \pi k}{T}+\phi\right),
$$

where $\mathrm{A}_{0}$ - annual average demand in physical terms;

A - amplitude of seasonal fluctuations;

$\mathrm{k}-$ month in the account period;

$\mathrm{T}$ - period (12 months);

$\varphi-$ shift in the time axis.

Yury Permyakov writes that "for practical calculations this formula should be transformed so that the required values of the model function can be included in the form of linear factors" [6]. In addition, the difference in the amplitudes of the two annual peaks of demand should be remembered (this is March - April and September - October for the group of companies "Avtotsentr KGS" ("Auto Centre CGS")). After taking into account these factors, the original model function takes the following form (formula 7). 


$$
\begin{aligned}
& f(k)=A_{0}+A_{1} \sin \left(\frac{2 \pi k}{T}\right)+B_{1} \cos \left(\frac{2 \pi k}{T}\right)+ \\
& +A_{1} \sin \left(\frac{4 \pi k}{T}\right)+B_{1} \cos \left(\frac{4 \pi k}{T}\right)
\end{aligned}
$$

The article of Yury Permyakov specifies that "the ratios A1, B1, A2 and B2 reflect the amplitudes of seasonal fluctuations within a period of six months and a year". According to the researcher, formula 7 represents the first three expansion terms in the Fourier series, which appeared with the stated frequency. "The formulae for calculating ratios are known from the theory of Fourier analysis. They can be determined by the following formulae" 8 $12[6]$.

$$
\begin{gathered}
A_{0}=\frac{1}{12} \sum_{k=1}^{12} g_{k} \\
A_{1}=\frac{1}{12} \sum_{k=1}^{12}\left[2 g_{k} \sin \left(\frac{2 \pi k}{12}\right)\right] \\
B_{1}=\frac{1}{12} \sum_{k=1}^{12}\left[2 g_{k} \cos \left(\frac{2 \pi k}{12}\right)\right] \\
A_{2}=\frac{1}{12} \sum_{k=1}^{12}\left[2 g_{k} \sin \left(\frac{4 \pi k}{12}\right)\right] \\
B_{2}=\frac{1}{12} \sum_{k=1}^{12}\left[2 g_{k} \cos \left(\frac{4 \pi k}{12}\right)\right]
\end{gathered}
$$

where $g_{k}-$ actual sales during the analysed period

Calculating the limit of acceptable growth in sales volume under the steady state model is conducted according to formula 13 .

$$
S G R=\frac{\Delta S}{S}=\frac{b \cdot \frac{N P}{S} \cdot\left(1+\frac{D}{E_{q}}\right)}{\frac{A}{S}-\left[b \cdot \frac{N P}{S} \cdot\left(1+\frac{D}{E_{q}}\right)\right]}
$$

where $\mathrm{A} / \mathrm{S}$ - ratio of total assets to sales value;

$\mathrm{NP} / \mathrm{S}$ - profit margin;

$\mathrm{b}$ - retention rate;

$\mathrm{D} / \mathrm{E}_{\mathrm{q}}-$ debt equity ratio;

$\Delta S$ - absolute change in sales volume compared to last year. 
The choice of the method according to the accounting item is primarily due to the type of production. In piece-work and small-scale production, it is advisable to use the production-order method, while the process method is used for large-scale or mass production. It is possible to combine these two methods at the same enterprise at different sites and production facilities.

When implementing business projects in digital entrepreneurship, the key method is the order one, the use of which is conditioned by the digital economy focus on the individual needs of the client. However, the economy of scale provided by using information and communication technology should lead to the parallel application of the process method typical for mass production. The technique for the interrelated use of these methods requires a special study.

The majority of Russian production enterprises use the full cost accounting method according to the completeness of cost accounting. This is due to use the rate of return method of pricing. The completeness of cost accounting requires considering the issue of distributing indirect costs depending on the selected cost item (order or process) and the costing item (cost driver) - order, products, service, work, project.

Incomplete cost accounting requires addressing the issue of dividing costs in the constant and variable parts simultaneously according to their classification into direct and indirect ones. There is a variety of methods for accounting incomplete production costs. Simple (single-stage) and developed direct-costing are most commonly considered.

The use of the normative method has been actively discussed in the literature for about a hundred years, but its use at production enterprises is difficult due to the need to at least annually develop a system of advanced norms and standards, review them, monitor deviations, analyse their causes and propose management solutions for their elimination, providing the existence of feedback loop. Currently, the normative method of accounting is considered in comparison with its foreign equivalent - the "standard-cost" method, while in fact the enterprises still form the actual cost price.

In the course of research, the author specifies the modern methods of cost management used by certain enterprises. These methods are also advisable to use while implementing business projects in digital entrepreneurship, they include budget management, direct costing, actions-based management, functional and cost analysis. We consider it important to note that as the course of changes accelerates, the leading role in improving the effectiveness is played not by certain tools and methods, but by their combination. Today, many management methods and programmes are merging.

We identify the advantages of budget management, which make it attractive for pursuing goals of cost management for implementing business projects in digital entrepreneurship.

1. Decentralising responsibility without risk of losing control over cost management;

2. Control over funds, including justifying and financing capital investments;

3. Profitability control according to the types of innovation activities and specific projects;

4. Management flexibility and the ability to make adjustments rapidly in unsatisfactory performance or changing market conditions;

5. Overall effectiveness of management due to prompt detection of divergences in achieving goals and elimination of their causes.

The key requirements of the budget method are: mandatory existence of well-regulated analytical accounting office at the enterprise and assignment of responsibility centres and analysis centres.

Direct costing establishes the links between costs and production volumes and allows fulfilling strategic and operational objectives of managing costs for business projects: 
choosing the most effective projects; assessing the possibility of establishing dumping prices to winning new markets; planning overheads and creating flexible budgets.

The action-based management generates information that allows employees to focus on the on-going improvement of quality, cost, flexibility, services, optimising time and increasing profitability.

The functional and value analysis presupposes a systematic study of the certain items functions (goods and processes) for reducing costs and obtaining effect. The use of functional and value analysis can pursue the following objectives: reducing cost; increasing productivity; increasing efficiency; improving quality; reorganisation; effective use of labour.

Cost management for implementing business projects in digital entrepreneurship poses challenges that in many respects require more efforts than in other business areas. Innovation activity based on applying information and communication technology covers a whole range of diverse activities. Each type of innovation has its own characteristic features and provides management techniques that are not applicable to other activities.

The study of the results dependence on the structure of costs for technological innovation shows that relatively increasing costs for acquiring patents, licenses for the use of inventions, industrial designs, utility models entails improving innovation results (volume and share of innovative products) in comparison with the costs of research and development. This research was published by the Internet journal Technological Business. It should be noted that enterprise specialists inadequate competence reduces the effectiveness of transactions on technology acquisition. For example, Russian enterprises practically do not take advantage of opportunities created by the operations that are widely used in the world, such as franchising, option, leasing. The chain "franchising - licensing leasing" allows minimising investments and solving a difficult problem in mastering advanced equipment and technology, manufacturing new goods and providing services and in the condition of seed capital deficit.

The concepts licensing and cross-licensing are new for Russia and they are interesting in relation to effective management of costs for innovative activities at the enterprises.

Successful cross-licensing is associated with the availability of a high-quality patent portfolio at the enterprise. It allows firms to get more revenue from innovation, to influence business negotiations. It gives the opportunity to stimulate the development of innovative technology and patents that do not copy, but complement the existing ones.

In Russia, most of the technologies transferred under license are not adopted in industry and are under development that increases the adoption risk and reduces the license price. Most Russian enterprises do not have common policy for protecting industrial property. A serious problem is the early transfer of scientific and technical knowledge without proper patent protection, industrial exploitation and necessary advertising. An important issue in organising Russian technologies export is the lack of information and license economic self-sufficiency.

Thus, the modern marketing conditions require the integrated methods and tools based on them that will be able to modernise the organisational and information structure and to initiate the effective use of cost management methods. Controlling can serve as such tool, this is the system of integrated managing financial performance in the organisation as a whole and its business projects in particular.

As part of the system approach to designing a cost management system for implementing business projects in digital entrepreneurship, the author proposes to use the concept of reengineering, based on the identification of cross-functional business processes.

It is advisable to use SADT (Structured Analysis and Design Technique) for creating a cost management system for enterprises for implementing business projects in digital entrepreneurship. 
The viable choice of methods for designing SADT is based on a comparative analysis of methods for describing systems: structured design method of Ed Yourdon, structured analysis method of Tom DeMarco, structured system analysis method of Christopher Gane and Trish Sarson, data structuring methods of Michael Jackson, Jean-Dominique Warnier and Kenneth Orr.

The Structured Analysis and Design Technique emerged in the late 1960s and by 1981 proved effective in 50 companies working on 200 projects covering the issues of long-term and strategic planning, computer-aided production, personnel training, financial management, material and technical supply, etc. The creators of SADT were committed to describe the system as a whole and invented a graphical language and a set of analysis procedures for understanding the system before it could be implemented. The use of SADT allows evaluating the effectiveness of the system at the early stages of its creation process, reducing costs for developing and operating the system, and increasing its reliability. SADT reduces the number of costly mistakes due to the system structuring at the early stages of its creation, improving contacts between users and developers, and smoothing the transition from analysing the system goals to its designing.

In terms of our research, the significant advantage of SADT is its aiming at highlighting such system features as management, feedback and performers.

The SADT methodological approach to designing the cost management system for implementing business projects in digital entrepreneurship transforms the classical management scheme into a model.

Structural and logical cognitive models of cost management at Russian enterprises, developed in the course of research, made it possible to identify the following major disadvantages in cost management for implementing business projects in digital entrepreneurship. These disadvantages include:

- lacking system approach to managing costs for implementing business projects;

- missing formalised external and corporate information communications in the process of innovation;

- lacking mechanism for coordinating related types of innovation, business projects and for creating a unified action platform;

- decisions in cost management for implementing business projects in digital entrepreneurship are made by the executives, without active involvement of scientists, specialists and workers. There is a problem of communication between R\&D (research and development) specialists, marketing experts and economists;

- missing formalised feedback from implementing units to managers;

- lacking operational management information on costs for innovation, business projects, types of innovation activities and business units. The personal responsibility of managers for individual work areas is not fixed, therefore, there is no person responsible for the final result.

The integrated processes for implementing innovation through reengineering should be organised for the effective operation of the modern cost management system for implementing business projects in digital entrepreneurship. The objective-oriented approach that is the fragmentation of work into its simplest components and its distribution among the corresponding specialists was the basis for organising and managing Russian and foreign companies for two centuries. At present, there is a shift in focusing from objectives to processes, and this shift consists in profound changes that have happened at leading foreign and Russian enterprises.

Michael Hammer and James Champy, the pioneers of reengineering, defined reengineering as the fundamental rethinking of business processes to achieve significant improvements in essential modern indicators of performance, such as costs, quality, service level and efficiency. 
The obligatory features of reengineering activities are:

- process orientation;

- great ambitions;

- break with rules.

- creative use of information technology.

The main trends of changes in business processes that have undergone reengineering are:

- combining several tasks, for which one authorised person is responsible ("situational worker");

- "vertical compression" or delegating private decision-making to performers;

- implementing process steps in the natural order ("elimination of processes linearity");

- applying many variants of processes;

- performing work where it is possible to make it more efficient;

- reducing inspection and control;

- minimising required approvals;

- using "situational managers" for contacts with the external environment;

- dominating mixed centralised and decentralised operations.

In the course of processes reengineering, the work assignments are evolving from highly specialised and task-oriented to more multidimensional ones. There is no sense in the functional departments. All specialists are guided by consumer needs. Reengineering of innovative processes allows integrating knowledge, abilities and work of R\&D specialists, marketing experts and economists in order to meet consumer needs in new products in the shortest possible time and at minimal cost.

In turn, the controlling system should cover all aspects of enterprise management. The use of controlling tools only in managing costs for implementing business projects in digital entrepreneurship will not produce the desire effect.

The development of the controlling system at the enterprise, as a rule, includes issues of organising the controlling service, defining its place in the organisational structure of the enterprise, analysing information flows and possible options for implementing.

The controlling system for managing costs for implementing business projects in digital entrepreneurship should ensure reporting on costs and revenues in the following areas:

- types of innovation;

- business projects;

- types of innovative activity;

- responsibility fields.

Division by responsibility fields should be used when the organisational plan identifies fields with a certain responsibility; there are various production facilities or sites (enterprises, offices, projects); different production processes are managed by different staff in charge.

The foundation for organising cost accounting by fields (centres) of responsibility is assigning costs for managers of various ranks and systematic monitoring compliance with estimates for each person in charge. Therefore, the first challenge in organising cost accounting by responsibility centres is the specification of these centres to secure responsibility.

The organisation of cost accounting according to the enterprise organisational structure allows connecting the activities and responsibilities of specific individuals with the costs incurred by the enterprise. For a business project comprising employees from different responsibility centres, a fictitious responsibility centre should be identified for accumulating and controlling project costs.

The next challenge is the development of estimates for each responsibility centre. 
Defining the accounting reporting items requires differentiating the enterprise costs. Costs are classified in such a way that the cause and effect relations between costs magnitude, certain decisions and developments are clearly visible.

To allocate costs in the reporting system, the following criteria should be applied:

- large amount of costs;

- marked fluctuations in costs in the periods of activity;

- higher costs than costs of competing enterprises;

- costs for which an enterprise can have competitive advantages;

- integrated nature of costs.

The accounts of the accounts business plan at the enterprise must be linked to reporting prepared, in which the grouping of costs is carried out by types.

Serious difficulties are caused by dividing costs for controlled and uncontrolled ones, since to assess the performance of each responsible person it is necessary to know the divergence from the estimate only in controlled expenses. Difficulties arise due to the fact that a significant part of the expenditure is partially controlled.

In the division of costs for controlled and uncontrolled, two factors are usually taken into account: level of management and time.

It is possible to achieve a nearly complete division of costs for controlled and uncontrolled through careful analysing each cost item at different levels of management and at different periods. In accordance with it, the responsibility centres are established by levels.

Particular attention is drawn to such cost items, which are partially controlled, but fully registered at this level. At the same time, special accounts or costs are sometimes defined in the analytical account and they are divided into two parts. The other side of this challenge is the classification of costs in case if the responsibility for this cost item is identified according to the factors.

An essential part of the system is the reporting for costs in accordance with the levels of responsibility. The report on each level is the most important document for assessing the activities of business units.

Thus, there is an objective need to reorganise the structure of cost management, due to both internal and external factors:

- globalisation of the market;

- stronger competition;

- cumulative changes in the external environment;

- customer domination at the market;

- decisive role of innovation in increasing production efficiency and achieving its ultimate goal;

- multi-stage process of developing and implementing new equipment and technology, combining different stages;

- specific features of innovation: uncertainty of costs and results, variability of research, risk and possibility of negative results, agility, implementation of innovative stages by different performers, and the results of each previous stage affect the effectiveness of subsequent and final results;

- significant role of the subjective factor and the psychological climate in the team;

- increasing costs and temporary deteriorating economic performance while developing new products;

- rapid moral aging of equipment and technology;

- unique character of research and development processes;

- temporary gap between development costs and effect of implementing the results;

- need for accelerated implementation of completed developments. 
Thus, the key trend in the change of the cost management structures is the decentralisation in managing costs for innovative activities, while maintaining centralised strategic decision-making and budgetary control. These changes correspond to the basic requirements of the competitive environment: flexibility and adaptability.

\section{Future research directions}

The study assumed that there is an opportunity to develop a methodology for cost management in Russian enterprises based on modern megatrends of environment development, regularities of subject behaviour and cost management object, as well as characteristics of the digital business.

Forming complex methodology of interrelated using job cost system and process cost system are of practical interest.

We believe that in a digital enterprise normative method of cost management will be updated at the next level that certainly will require the development of guidelines on the application of normative method in terms of use information and communication technologies.

Implemented in the study simulation model of cost management and funds for realization of business projects needs some work on the following:

- search for adequate studied parameters of distribution laws;

- establishment of the complex interrelationships between model indicators reflecting the most significant factors of cost management and funds in the digital economy.

The implementation of multiple cognitive models will identify significant relationship and laws of functioning and development of cost management system on realization of business projects of digital entrepreneurship

\section{Conclusion}

As a part of scientific research the theory and practice of cost management has been studied. There was an attempt to identify the developments determined by the specificity of innovation, implementing business-projects, using information and communication technologies. Cut from a general academic research level to application development of practitioners based on the use of systematic, integrated, cognitive approaches and simulation allows us to speak about the need for further creative adaptation of the results obtained. Implementation of qualitative leap by theoretical reflection on the findings and data will provide practice tools for effective use of information and communication technologies. Primarily the theory should be tested in the services sector, which is already changing dynamically in the digital economy. Implementation of business projects in other fields and sectors will require more time and effort.

The reported study was funded by the Russian Foundation for Basic Research (RFBR) according to the research project No. 18-010-00204.

\section{References}

1. World Bank, World development report 2016: digital dividends: an overview (World Bank, Washington, DC, 2016)

2. Yu. Brigham, L. Gapenski, Ekonomicheskaya shkola, 2 (1998) 
3. Ye. N. Zakharova, Bulletin of the Adyghe State University - Series 1: Regional Studies: Philosophy, History, Sociology, Jurisprudence, Political Science, Culturology, 3 (2007)

4. A. Lednev, Financial Director, 5 (2012)

5. D. Medvedev, Economic Issues, 10 (2015)

6. Yu. Permyakov, Financial Director, 6 (2012)

7. A. Repyev, Do we have a place in "new economy"? (http://www.repiev.ru/articles.htm)

8. M. Z. Svitkin, Management Theory and Practice, 1, 59 (2008) 